\title{
Distinct Clinical Characteristics of Familial and Solitary Patients with Bipolar Disorder
}

\author{
Murat ilhan Atagün ${ }^{1}$, Esra Sena Cevahirli¹, Tug̃ba Kara ${ }^{1}$, Sencer Tabakçı1, \\ Özlem Devrim Balaban ${ }^{1}$, Dilek Yeșilbaș ${ }^{1}$
}

ÖZET:

iki uçlu bozuklug̃u olan ailesel ve münferit hastaların farklı klinik özellikleri

Amaç: iki uçlu bozukluk da dahil majör ruhsal bozukluklar ailelerde kümelenmektedirler. Ailesel olmayan, tek vakalar da görülmektedir ve ailesel ve ailesel olmayan vakalar klinik özellikler bakımından farklıık gösterebilirler. Aileselliḡi dikkate alan çalıșmaların büyük bölümü aynı aileden hastalarda hastalığın benzer olan ve olmayan özelliklerini incelemișlerdir. Farklı ailelerden olan ve ailesel özelliklerine göre hastalık özelliklerinin karșılaștıııldıg̃ı yeterince çalıșma yoktur. Bu çalışmada ailesel olan ve olmayan tip I iki uçlu bozuklug̃u olan hastaların klinik özellikler açısından incelenmesi ve karşılaştııılması amaçlanmıştır.

Yöntem: Bu araștırma Bakırköy Prof. Dr. Mazhar Osman Ruh ve Sinir Hastalıkları Eg̃itim ve Araștırma Hastanesine bag̃lı Rașit Tahsin Duygudurum Merkezi'nde tedavi görmekte olan hastalarla yapıldı. ỉki uçlu bozuklug̃u olan 112 hastanın (69 kadın, 43 erkek, ortalama yaș: $41.54 \pm 11.19$, dag̃ılım aralıg̃ı: 22-75, ailesinde hastalık öyküsü olan 64, olmayan 48 hasta) tıbbi kayıtları incelendi ve veriler hastalardan ve birinci derece akrabalarından telefonla teyit edildi. Ailesinde hastalık öyküsü olmayan hastaların ailelerine sorularak ailelede bașka hastanın olmadı̃̃ dog̃rulandı. Bulgular: Psikiyatrik ekhastalıklar, dog̃um sonrası depresyon oranları, nikotin bag̃ımlıı̃̃ı, karma hastalık dönemi geçirmiş hasta sayısı ve halen antipsikotik kullanan hasta sayısı aile öyküsü olan hasta grubunda istatistiksel olarak anlamlı derecede daha fazla oldukları saptanan özelliklerdi. Hastalık bașlangıc yașı, hastalık dönemi sayıları ve hastaneye yatış sayiları açısından gruplar arasında fark saptanmadı. Sonuç: Psikiyatrik ekhastalık, dog̃um sonrası depresyon, karma hastalık dönemleri ve sigara kullanma ailesinde hastlalık öyküsü olan hastalarda daha fazla oranda bulundukları tespit edilen klinik özelliklerdir ve iki uçluluk ile ilişkilidirler. Psikiyatrik ekhastalık ve postpartum dönem geçirmeye yatkınlık aile öyküsü olan hastalarda daha fazla görülmesi beklenebilir. Fakat klinik özelliklerin gruplarda farklılık gösterip göstermediāinin belirlenebilmesi için daha bașka büyük örneklemli çalıșmalar da gerekmektedir.

Anahtar sözcükler: Ailesel, ailesel olmayan, iki uçlu bozukluk

Journal of Mood Disorders 2011;1(3):110-7
ABSTRACT:

Distinct clinical characteristics of familial and solitary patients with bipolar disorder

Objective: Major mental disorders including bipolar disorder aggregate in families. There are also non-familial, solitary cases and familial and non-familial cases may differ. Most of the studies regarding familiality in bipolar disorder targeted similar and dissimilar characteristics of the disease within families. There is a lack of studies targeting between subject differences in patients from different families. The aim of this study is to assess and compare clinical characteristics of type I bipolar patients with and without a family history of bipolar disorders.

Method: This study was conducted on outpatients of Rașit Tahsin Mood Disorders Centre of Bakırköy Research and Training Hospital. The medical records of 112 participants (69 female, 43 male, mean age: $41.54 \pm 11.19$, range: $22-75,64$ of which had family history and 48 without family history) with type I Bipolar Disorder were collected. Missing information was obtained by phone interviews from both patients and first degree relatives. Information of the patients without a family history of any psychiatric disorder was checked with a senior family member.

Results: Postpartum episode rates, comorbid psychiatric disorders, number of subjects ever had past mixed episodes, and nicotine dependency rates were found to be significantly higher in patients with family history. No significant difference was detected between groups in terms of age, gender, education, age at disease onset, number of episodes, and number of hospitalizations.

Conclusions: Comorbidity, postpartum episodes, lifetime mixed episodes, and smoking were found to be highe in patients with family history and thus associated with bipolarity. Postpartum episodes and comorbidities can be expected to be more prevalent in patients with family history. However clinical characteristics should be further investigated in larger samples.

Key words: Familial, non-familial, bipolar disorder

Journal of Mood Disorders 2011;1(3):110-7
'Bakırköy Research and Training Hospital for Psychiatry, Neurology and Neurosurgery, istanbul-Turkey

Yazıșma Adresi / Address reprint requests to: Dr. Murat ilhan Atagün, $5^{\text {th }}$ Psychiatry Department, Bakırköy Research and Training Hospital for Psychiatry and Neurology, Demirkapı Cd. Zuhuratbaba, Bakırköy 34147 İstanbul-Turkey

Telefon / Phone: +90-212-543-6565/1106

Faks / Fax: +90-212-660-3222

Elektronik posta adresi / E-mail address: muratilhanatagun@gmail.com

Kabul tarihi / Date of acceptance: 16 Ag̃ustos 2011 / August 16, 2011

Bag̃ıntı beyanı:

M. I. E S.C. T.K S. Ö.D.B. D.Y. Yazarlar bu makale ile ilgili olarak herhangi bir çıkar catıșması bildirmemișlerdir.
Declaration of interest:

M.I.A., E.S.C., T.K., S.T., Ö.D.B., D.Y.: The authors reported no conflict of interest related to this article.

\section{INTRODUCTION}

Major mental disorders aggregate in families. The risk of developing bipolar disorder is $8.7 \%$ in first degree relatives of bipolar probands and the same is $14.1 \%$ in unipolar depression (1). A variety of linkage findings emerged successfully $(2,3)$ and there are some significant findings at genome-wide levels $(4,5)$ in bipolar disorders. 
However phenotypic heterogeneity is a major barrier to find out more consistent results and there is a lack of phenotypic traits to homogenize psychotic spectrum disorders. The concept endophenotype has been a prospect to detect traits to refine phenotypes and define subgroups. On the other hand better identifying variations of clinical variables in different subgroups may provide predictions of clinical traits to be candidates for endophenotype concept. Familial clustering of a symptom may indicate a shared genetic origin and puerperal mood disorders are instances shown to be largely familial traits (6-11).

A number of studies focusing on the differences between familial aggregated and solitary cases provided promising data. The course and severity of the disease is shown to correlate between affected relatives in schizophrenia $(12,13)$. Findings regarding age of onset (14-16), course of disorder, premorbid functioning, and impairment during disorder (17) pointed out modest similarity within families. Some other studies found higher severity of negative symptoms (18-20), poorer outcome, and higher rates of hospitalizations (21) in familial patients. Lui and colleagues (22) compared familial and sporadic cases with magnetic resonance imaging and found that familial cases had more severe structural abnormalities than sporadic cases, particularly in the thalamus. Genetic studies have shown that to some extent schizophrenia and bipolar disorders overlap and share susceptibility loci $(23,24,25)$. If there are differences between familial and non-familial cases in schizophrenia, then it is possible to expect differences between familial and non-familial forms of bipolar disorder.

Mood disorders are also studied in large samples with different methods. Fistalen and colleagues (26) examined 407 subjects from 86 families and investigated familial resemblance of number of episodes and episode frequency per year. They found that episode frequency is a highly familial trait. Schulze and colleagues (27) investigated 1246 individuals from 172 multiplex families and found that alcohol and substance abuse, psychosis, history of suicide attempts, and level of social functioning was familial, but clinical subtype, age at onset, and comorbid panic disorder did not show familial dispersion in the large sample. O'Mahony et al (28) found significant within-pair correlation for age at onset and degree of psychosis in a sample with 160 families with mood disorders. In a recent study with a Turkish sample, patients with type I and II bipolar disorder and unipolar depression were grouped and compared according to family history (29). The patients with a family history were reported to have earlier age at onset in this study. Kassem and colleagues (5) studied 971 subjects from 507 families of patients with type I bipolar disorder and schizoaffective disorder and found that polarity at illness onset is a familial feature of bipolar disorders. In a large Danish cohort study, Steinhausen and colleagues (30) demonstrated that mental disorders including bipolar disorder aggregate in families with some differential patterns. Authors also reported that in families, mood disorders were strongly specified to probands' disorder, unlikely to schizophrenia.

Most of the studies regarding familiality in bipolar disorder targeted similar and dissimilar characteristics of the disease within families. There is a lack of studies targeting subject differences among different families. Besides, most studies were done with heterogeneous samples including type I and II bipolar disorder, schizoaffective disorder and depressive disorders. Hence we aimed to compare familial and non-familial cases with type I bipolar disorder in terms of clinical variables to assess differences in clinical characteristics of the groups.

\section{METHODS and PATIENTS}

This study was done with outpatients of Raşit Tahsin Mood Disorders Centre of Bakırköy Research and Training Hospital between November 2010 and January 2011. The current medical records of 112 participants (69 female, 43 male, mean age: $41.54 \pm 11.19$, range: 22-75) with type I Bipolar Disorder were collected. Investigations of medical records and interviews were done with guidance of a form including sociodemographic and clinical characteristics, psychiatric and medical history, and family history. All of the participants gave a written informed consent.

Subjects with a family history of mood and psychotic disorders were enrolled into group 1. Subjects without a family history were enrolled into group 2 . The family history was limited to first and second degree relatives. Relatives were accepted to have the disease only if they 


\begin{tabular}{|c|c|c|c|c|}
\hline & $\begin{array}{l}\text { All Subjects } \\
\quad(n=112)\end{array}$ & $\begin{array}{c}\text { Group } 1 \\
(n=64)\end{array}$ & $\begin{array}{c}\text { Group } 2 \\
(n=48)\end{array}$ & $\mathbf{p}$ \\
\hline Age & $41.54 \pm 11.2$ & $41.27 \pm 11.28$ & $41.9 \pm 11.17$ & 0.77 \\
\hline Education ${ }^{*}$ & $8.39 \pm 3.9$ & $8.77 \pm 4.01$ & $7.9 \pm 3.72$ & 0.24 \\
\hline Age at Disease Onset & $21.6 \pm 7.69$ & $22.25 \pm 8.49$ & $20.73 \pm 6.47$ & 0.3 \\
\hline Total Number of Episodes & $10.43 \pm 8.74$ & $11.02 \pm 9.62$ & $9.65 \pm 7.43$ & 0.41 \\
\hline Number of Hospitalizations & $3.35 \pm 4.69$ & $2.97 \pm 4.41$ & $3.85 \pm 5.04$ & 0.33 \\
\hline
\end{tabular}

"t test; Group 1: Patients with family history; Group 2: Patients without family history; ¥: Years

were diagnosed by clinicians. Missing information was obtained by phone interviews from both patients and first degree relatives. The information of the patients without a family history of any psychiatric disorder was checked with a senior family member by phone interviews. The information regarding premenstrual dysphoria, lifetime suicide attempt, nicotine dependency was obtained from declaration of the patients. The information regarding mixed episode, rapid cycling, episodes with psychotic, melancholic or catatonic features, psychiatric comorbidities and postpartum depression were based on diagnoses given by clinicians.

The patients with neurological diseases, mental retardation, type II and III bipolar disorder, schizoaffective disorder, atypical forms of bipolar disorders, and unclear family history were excluded. 64 families had more than one member with bipolar disorder. 45 of the families had only the patients with bipolar disorder. 9 families had both members with bipolar disorder and unipolar depressive disorder. 8 families had members with schizophrenia as well as members with bipolar disorder. 2 families had members with anxiety disorders as well as members with bipolar disorder.

\section{Statistical Analyses}

SPSS 17.0 for Windows was the software used. Patients were grouped as they have a family history of Bipolar Disorder (group 1) or without a family history of any psychiatric disorder (group 2). Groups were compared in terms of clinical characteristics. Continuous variables were compared with t test and categorical variables were compared with Chi-square test. And p values lower than 0.05 were accepted as statistically significant. Furthermore, for variables showing statistically significant difference, odds ratios and \%95 confidence intervals were obtained.

\section{RESULTS}

Sociodemographic and clinical data are given in Table 1 and 2 . There were no statistically significant difference between groups in terms of age, gender, and education. There was no significant difference between groups in terms of age at disease onset, total number of episodes, number of hospitalizations and history of episodes with psychotic, catatonic or melancholic characteristics.

Number of nicotine dependent individuals was significantly higher in patients with family history ( $p=0.029, \chi^{2}$ : 4.78, RR: 2.35, \%95 CI: 1.09-5.07) (Table 2). There were significantly higher numbers of patients "ever had mixed episodes" ( $\mathrm{p}=0.014, \chi^{2}: 6.05$, RR: 3.63, \%95 CI: 1.25-10.59) in patients with family history (Table 2).

Patients with comorbidities are given in table 3. 19 patients with family history had comorbid psychiatric disorders, while only 7 of the patients without family history had comorbidities. There was significant difference between groups in terms of comorbidities ( $\mathrm{p}=0.003, \chi^{2}: 8.95$, RR: 4.01, \%95 CI: 1.56-10.3).

Postpartum episode ( $\mathrm{p}=0.006, \chi^{2}: 7.49$, RR: 5.88, \%95 CI: 1.52-22.97) (Table 4) rates were significantly higher in patients with family history. Although there was a significant difference between groups in terms of premenstrual dysphoria $\left(\mathrm{p}=0.001, \chi^{2}=10.97\right)$ and number of subjects ever had electroconvulsive therapy $(\mathrm{p}<0.001$, $\chi^{2}=12.51$ ), according to relative risks there was not statistically significant difference between groups (RR: 0.15, \%95 CI: 0.05-0.49 and RR: 0.23; \%95 CI: 0.1-0.53 respectively). 
Table 2: Subjects Characteristics (Categorical variables)

\begin{tabular}{|c|c|c|c|c|c|c|}
\hline & $\begin{array}{c}\text { All Subjects } \\
(n=112)\end{array}$ & $\begin{array}{l}\text { Group } 1 \\
(n=64)\end{array}$ & $\begin{array}{c}\text { Group } 2 \\
(n=48)\end{array}$ & $\chi^{2}$ & $\begin{array}{c}\text { RR } \\
(\% 95 \mathrm{Cl})\end{array}$ & $\mathbf{p}$ \\
\hline Gender (Female/Male) & $69 / 43$ & $37 / 27$ & $32 / 16$ & 0.91 & $\begin{array}{c}1.46 \\
(0.67-3.18)\end{array}$ & 0.34 \\
\hline Nicotine Dependency & $\begin{array}{c}53 \\
(\% 47.3)\end{array}$ & $\begin{array}{c}36 \\
(\% 56.3)\end{array}$ & $\begin{array}{c}17 \\
(\% 35.4)\end{array}$ & 4.78 & $\begin{array}{c}2.35 \\
(1.09-5.07)\end{array}$ & 0.029 \\
\hline Psychiatric Comorbidity & $\begin{array}{c}33 \\
(\% 29.4)\end{array}$ & $\begin{array}{c}26 \\
(\% 40.6)\end{array}$ & $\begin{array}{c}7 \\
(\% 14.6)\end{array}$ & 8.95 & $\begin{array}{c}4.01 \\
(1.56-10.3)\end{array}$ & 0.003 \\
\hline Rapid Cycling & $\begin{array}{c}27 \\
(\% 24.1)\end{array}$ & $\begin{array}{c}19 \\
(\% 29.7)\end{array}$ & $\begin{array}{c}8 \\
(\% 16.7)\end{array}$ & 2.54 & $\begin{array}{c}2.11 \\
(0.83-5.35)\end{array}$ & 0.111 \\
\hline Mixed Episodes & $\begin{array}{c}24 \\
(\% 21.4)\end{array}$ & $\begin{array}{c}19 \\
(\% 29.7)\end{array}$ & $\begin{array}{c}5 \\
(\% 10.4)\end{array}$ & 6.05 & $\begin{array}{c}3.63 \\
(1.25-10.59)\end{array}$ & 0.014 \\
\hline Melancholic Episode & $\begin{array}{c}11 \\
(\% 9.8)\end{array}$ & $\begin{array}{c}7 \\
(\% 10.9)\end{array}$ & $\begin{array}{c}4 \\
(\% 4.8)\end{array}$ & 0.21 & $\begin{array}{c}1.35 \\
(0.37-4.91)\end{array}$ & 0.647 \\
\hline Catatonic Episode & $\begin{array}{c}8 \\
(\% 7.1)\end{array}$ & $\begin{array}{c}4 \\
(\% 6.2)\end{array}$ & $\begin{array}{c}4 \\
(\% 8.3)\end{array}$ & 0.18 & $\begin{array}{c}0.73 \\
(0.17-3.14)\end{array}$ & 0.672 \\
\hline Psychotic Episodes & $\begin{array}{c}82 \\
(\% 73.2)\end{array}$ & $\begin{array}{c}50 \\
(\% 78.1)\end{array}$ & $\begin{array}{c}32 \\
(\% 66.7)\end{array}$ & 1.84 & $\begin{array}{c}1.79 \\
(0.77-4.15)\end{array}$ & 0.175 \\
\hline $\begin{array}{l}\text { Subjects ever had } \\
\text { ECT treatment }\end{array}$ & $\begin{array}{c}65 \\
(\% 58)\end{array}$ & $\begin{array}{c}28 \\
(\% 43.8)\end{array}$ & $\begin{array}{c}37 \\
(\% 77.1)\end{array}$ & 12.51 & $\begin{array}{c}0.23 \\
(0.1-0.53)\end{array}$ & $<0.001$ \\
\hline Suicide Attempt & $\begin{array}{c}43 \\
(\% 38.4)\end{array}$ & $\begin{array}{c}29 \\
(\% 45.3)\end{array}$ & $\begin{array}{c}14 \\
(\% 29.2)\end{array}$ & 3.02 & $\begin{array}{c}0.49 \\
(0.23-1.01)\end{array}$ & 0.082 \\
\hline
\end{tabular}

Chi-Square test, RR: Relative Risk; Cl: Confidence Interval; Group 1: Patients with Family History; Group 2: Patients without Family History; ECT: Electroconvulsive Therapy.

\section{Table 3: Distribution of Comorbidities}

\section{All Subjects $(n=112)$}

Patients without Comorbidity Patients with Comorbidity Anxiety Disorders Obsessive Compulsive Disorder Alcohol and Substance Abuse Eating Disorders Personality Disorders Post Traumatic Stress Disorder

$86(\% 76.8)$

$26(\% 23.2)$

6

6

8

2

3

1

23.2)
6
8
8

Group $1(n=64)$

$45(\% 70.3)$

$19(\% 29.7)$

5

6

5

1

2
Group 2 ( $n=48)$

$41(\% 85.4)$

7 (\%14.6)

1
0
3
1
1
1

Group 1: Patients with Family History; Group 2: Patients without Family History

Table 4: Premenstrual Dysphoria and Postpartum Depression Rates in Female Patients

\begin{tabular}{lccccc} 
& $\begin{array}{c}\text { All Females } \\
(\mathbf{n = 6 9 )}\end{array}$ & $\begin{array}{c}\text { Group 1 } \\
(\mathbf{n = 3 7 )}\end{array}$ & $\begin{array}{c}\text { Group 2 } \\
(\mathbf{n = 3 2})\end{array}$ & $\begin{array}{c}\chi^{\mathbf{2}} \\
\mathbf{R . R .}\end{array}$ \\
\hline Premenstrual Dysphoria & $44(\% 63.8)$ & $17(\% 45.9)$ & $27(\% 84.4)$ & 10.97 & $\begin{array}{c}0.15 \\
(0.05-0.49)\end{array}$ \\
Postpartum Depression & $17(\% 24.6)$ & $14(\% 37.8)$ & $3(\% 9.4)$ & 7.49 & $\begin{array}{c}5.88 \\
(1.51-22.97)\end{array}$ \\
\hline
\end{tabular}

Chi-Square test; RR: Relative Risk; Cl: Confidence Interval 


\section{DISCUSSION}

Postpartum episode frequency, number of patients with comorbid psychiatric disorders, number of subjects ever having past mixed episodes, and nicotine dependency rates were significantly higher in patients with family history. No significant difference was detected between groups in terms of age at disease onset, number of episodes, and number of hospitalizations.

Liability to postpartum episodes clusters in families (6-11) and postpartum episodes are suggested to be a familial form of bipolar disorder. Jones and Craddock (6) conducted a study with 313 births of 152 women with bipolar disorder. They found that women with family history of postpartum depression have greater tendency to postpartum episodes. Jones and Craddock (31) investigated family histories of 103 probands with bipolar disorder, 52 of which had postpartum episodes. They found that morbidity risk of mood disorders in first degree relatives of bipolar females was significantly higher than bipolar women with no episodes in the postpartum period. The authors commented that postpartum episodes identify a more familial subtype of bipolar disorder.

The postpartum episodes occur in 20 to $30 \%$ of pregnancies of women with bipolar disorder (32). Family studies regarding postpartum episodes show familial aggregation of psychiatric disorders with morbidity risks for first degree relatives in range from 10 to $50 \%(33,34,35)$. Higher prevalence of mood disorders in relatives of subjects with postpartum episodes suggests a major overlap in familial factors predisposing to postpartum episodes (6).

Number of patients with history of postpartum episodes was associated with familial aggregation of mood disorders in our study; but this finding is not in line with the researches regarding within family clustering. The groups of this study consisted of patients from different families and no other family members were enrolled. Instead, our aim was to find out if there is any association between bipolarity (familiality) and postpartum episodes. We found a higher postpartum episode rate among patients with family history of bipolar disorder and this finding indicates a relationship between postpartum episodes and familial features of genetic underpinnings of the disorder.
According to Schulze et al study (27) comorbid alcohol and substance abuse was found to be familial but panic disorders was not. On the contrary, risk for panic disorder in familial bipolar disorder was found to be higher in some studies $(36,37)$. On the other hand, it is possible to comment that alcohol and substance abuse may cluster in families due to shared environment and learned patterns of behavior. Interestingly, MacKinnon and colleagues (37) reported that relatives of the patients with panic attacks were less likely to have substance abuse diagnosis then the relatives of probands without panic attacks. Although we found a greater prevalence of general comorbidity including anxiety disorders as well as alcohol and substance abuse; small sample size does not let us to further investigate subgroups. The higher comorbidity rates in patients with family history may be an indicator of increased genetic interference.

Having lifetime mixed episodes and rapid cycling may indicate more severe disease and necessitates reconsidering treatment options. Although we found a higher rate of mixed episodes in familial patients, age at disease onset, rapid cycling, psychotic episodes and other clinical features did not show significant difference between groups. We found a higher prevalence of history of ECT treatment in patients without family history. This finding may be an indicator of more severe disease in this group. On the other hand this finding may also indicate that this group of patients may be less responsive to mood stabilizers and episodes become more severe depending on this. Follow up studies are needed to prove this finding and to probe the reasons of higher ECT needs in treatments. Age of onset was found to be significantly earlier in patients with family history in two studies $(25,39)$, however both of these studies have small sample sizes ( $\mathrm{n}=150$ and $\mathrm{n}=130$ respectively) and a study with a large sample size $(n=1246)$ (27) reported no significant difference between groups in terms of age at disease onset. Age at disease onset did not differ between the groups in this study. We also found higher rates of nicotine dependency in patients with family history. Smoking is assumed to be a measure of disease severity as well as caffeine consumption and alcohol and substance abuse (40). Psychosis $(41,42)$ and suicide attempts $(43,44)$ are also found to be related to smoking in patients with bipolar disorder. However, many factors may have 
influences on nicotine consumption and this is a small sample to obtain generalizable results in terms of smoking. Studies with larger sample sizes are needed to determine differences in clinical features between familial and non-familial patients.

The concept "familiality" is problematic to classify in several ways and should be delineated more circumstantially. The sample of this retrospective study consists of outpatients of a specialized centre for bipolar disorders and thus results cannot be generalized. All families of the patients assigned to group 1 included patients with bipolar disorder; but 8 families also had members with schizophrenia and 2 families also had members with anxiety disorders. Enrolling pure bipolar families may have increased homogeneity. Obtaining missing data and family history with phone interviews are other limitations of this study. It would be better to obtain these data in interviews in person. It may be a better way to enroll all family members and scan syndromal and subsyndromal cases together to optimize reliability. Another limitation was that some information (i.e. premenstrual dysphoria, lifetime history of suicide attempts) was obtained from patients by self reports. On

\section{References:}

1. Smoller JW, Finn CT. Family, twin, and adoption studies of bipolar disorder. Am J Med Genet C Semin Med Genet 2003;123:48-58

2. Segurado R, Detera-Wadleigh SD, Levinson DF, Lewis CM, Gill M, Nurnberger JI Jr, Craddock N, DePaulo JR, Baron M, Gershon ES, Ekholm J, Cichon S, Turecki G, Claes S, Kelsoe JR, Schofield PR, Badenhop RF, Morissette J, Coon H, Blackwood D, McInnes LA, Foroud T, Edenberg HJ, Reich T, Rice JP, Goate A, McInnis MG, McMahon FJ, Badner JA, Goldin LR, Bennett P, Willour VL, Zandi PP, Liu J, Gilliam C, Juo SH, Berrettini WH, Yoshikawa T, Peltonen L, Lonnqvist J, Nothen MM, Schumacher J, Windemuth C, Rietschel M, Propping P, Maier W, Alda M, Grof P, Rouleau J, Del Favero J, Van Broeckhoven C, Mendlewicz J, Adolfsson R, Spence MA, Luebbert H, Adams LJ, Donald JA, Mitchell PB, Barden N, Shink E, Byerley W, Muir W, Visscher PM, Macgregor S, Gurling H, Kalsi G, McQuillin A, Escamilla MA, Reus VI, Leon P, Freimer NB, Ewald H, Kruse TA, Mors O, Radhakrishna U, Blouin JL, Antonarakis SE, Akarsu N. Genome scan meta-analysis of schizophrenia and bipolar disorder, part III: bipolar disorder. Am J Hum Genet 2003;73:49-62.

3. Badner JA, Gershon ES. Meta-analysis of whole-genome linkage scans of bipolar disorder and schizophrenia. Mol Psychiatry 2002;7:405-411

4. McQueen MB, Devlin B, Faraone SV, Nimgaonkar VL, Sklar P, Smoller JW, Abou Jamra R, Albus M, Bacanu SA, Baron M, Barrett TB, Berrettini W, Blacker D, Byerley W, Cichon S, Coryell W the other hand, if there are multiple patients in a family, attitude towards patients and illness may change and affect the course of the disorder. Than control for attitudes towards the disorder, support from families, caregiver burden, and interpersonal interactions must be taken into account in future studies. Studies focusing on inheritance models should be done in much more bigger samples in order to reduce probability of type one and two errors.

To conclude, in general, this study modestly suggests that patients with family history might be expected to be influenced by more aspects of the disorder. In particular, postpartum episodes and psychiatric comorbidity are largely familial aspects. Studies have been focusing on familial characteristics of familial aggregated samples in bipolar disorder. Although we aimed to distinguish differential clinical features of familial and non-familial patients, small sample size did not let us to explore differences between groups in terms of other clinical characteristics. The familial and non-familial forms of the disorder should be investigated in larger samples in order to detect specific clinical features of subgroups in bipolar disorder.

Craddock N, Daly MJ, Depaulo JR, Edenberg HJ, Foroud T, Gill M, Gilliam TC, Hamshere M, Jones I, Jones L, Juo SH, Kelsoe JR, Lambert D, Lange C, Lerer B, Liu J, Maier W, Mackinnon JD, McInnis MG, McMahon FJ, Murphy DL, Nothen MM, Nurnberger JI, Pato CN, Pato MT, Potash JB, Propping P, Pulver AE, Rice JP, Rietschel M, Scheftner W, Schumacher J, Segurado R, Van Steen K, Xie W, Zandi PP, Laird NM. Combined analysis from eleven linkage studies of bipolar disorder provides strong evidence of susceptibility loci on chromosomes $6 \mathrm{q}$ and 8q. Am J Hum Genet 2005;77:582-595.

5. Kassem L, Lopez V, Hedeker D, Steele J, Zandi P; The NIMH Genetics Initiative Bipolar Disorder Consortium, McMahon FJ. Polarity at onset is a familial feature of bipolar affective disorder. Am J Psychiatry 2006;163:1554-1560.

6. Jones I, Craddock N. Familiality of the Puerperal Trigger in Bipolar Disorder: Results of a Family Study. Am J Psych 2001;158:913-917.

7. Forty L, Jones L, Macgregor S, Caesar S, Cooper C, Hough A, Dean L, Dave S, Farmer A, McGuffin P, Brewster S, Craddock N, Jones I: Familiality of postpartum depression in unipolar disorder: results of a family study. Am J Psychiatry 2006;163:1549-1553.

8. Murphy-Eberenz K, Zandi PP, March D, Crowe RR, Scheftner WA, Alexander M, McInnis MG, Coryell W, Adams P, Depaulo JR Jr, Miller EB, Marta DH, Potash JB, Payne J, Levinson DF: Is perinatal depression familial? J Affect Disord 2006;90:49-55. 
9. Jones I, Hamshere M, Nangle JM, Bennett P, Green E, Heron J, Segurado R, Lambert D, Holmans P, Corvin A, Owen M, Jones L, Gill M, Craddock N: Bipolar affective puerperal psychosis: genome-wide significant evidence for linkage to chromosome 16. Am J Psychiatry 2007;164:1099-1104.

10. Payne JL, Mackinnon DF, Mondimore FM, McInnis MG, Schweizer B, Zamoiski RB, McMahon FJ, Nurnberger JI Jr, Rice JP, Scheftner W, Coryell W, Berrettini WH, Kelsoe JR, Byerley W, Gershon ES, Depaulo JR Jr, Potash JB: Familial aggregation of postpartum mood symptoms in bipolar disorder pedigrees. Bipolar Disord 2008;10:38-44.

11. Mahon PB, Payne JL, MacKinnon DF, Mondimore FM, Goes FS, Schweizer B, Jancic D; NIMH Genetics Initiative Bipolar Disorder Consortium; BiGS Consortium, Coryell WH, Holmans PA, Shi J, Knowles JA, Scheftner WA, Weissman MM, Levinson DF, DePaulo JR Jr, Zandi PP, Potash JB. Genome-wide linkage and follow-up association study of postpartum mood symptoms. Am J Psychiatry 2009;166:1229-1237.

12. Burke JG, Murphy JC, Bray D, Walsh D, Kendler KS. Clinical similarities in siblings with schizophrenia. Am J Med Genet 1996;67:239-243.

13. Kendler KS, Karkowski-Shuman L, O'Neill FA, Straub RE, Maclean CJ, Walsh D. Resembla nce of psychotic symptoms and syndromes in affected sibling pairs from the Irish study of high density schizophrenia families: evidence for possible etiologic heterogeneity. Am J Psych 1997;154:191-198.

14. Kendler KS, Tsuang MT, Hays P. Age at onset in schizophrenia: a familial perspective.Archives of General Psychiatry 1987;44:881-890.

15. Kendler KS, Maclean CJ. Estimating familial effects on age of onset and liability to schizophrenia.I. Results of a large sample family study.Genet Epidemiol 1990;7:409-417.

16. Ritsner M, Ratner Y, Gibel A, Weizman R. Familiality in a fivefactor model of schizophrenia psychopathology: findings from a 16-month follow-up study. Psychiatry Res 2005;136:173-179.

17. Wickham H, Walsh C, Asherson P, Gill M, Owen MJ, McGuffin P, Murray R, Sham P. Familiality of clinical characteristics in schizophrenia. J Psychiatr Res 2002;36:325-329.

18. Silverman JM, Mohs RC, Davidson M, Losonczy MF, Keefe RSE, Breitner JCS, Sorokin JE, Davis KL. Familial schizophrenia and treatment response. Am J Psych 1987;144:1271-1276.

19. Vazquez-Barquero JL, Cuesta Nunez MJ, Herrera Castanedo S, Diez Manrique JF, Pardo G, Dunn G. Sociodemographic and clinical variables as predictors of the diagnostic characteristics of first episodes of schizophrenia. Acta Psychiat Scand 1996;94:149-155.

20. Malaspina D, Goetz RR, Yale S, Berman A, Friedman JH, Tremeau F, Printz D, Amador X, Johnson J, Brown A, Gorman JM. Relation of familial schizophrenia to negative symptoms but not to the deficit syndrome. Am J Psych 2000;157:994-1003.

21. Feldmann R, Hornung WP, Buchkremer G, Arolt V. The influence of familial loading on the course of schizophrenic symptoms and the success of psychoeducational therapy. Psychopathology 2000;34:192-197.

22. Lui S, Deng W, Huang X, Jiang L, Ouyang L, Borgwardt SJ, Ma X, Li D, Zou L, Tang H, Chen H, Li T, McGuire P, Gong Q. Neuroanatomical differences between familial and sporadic schizophrenia and their parents: an optimized voxel-based morphometry study. Psychiatry Res 2009;171:71-81.
23. Badner JA, Gershon ES. Meta-analysis of whole-genome linkage scans of bipolar disorder and schizophrenia. Mol Psychiatry 2002;7:405-411.

24. Berrettini WH. Are schizophrenic and bipolar disorders related? A review of family and molecular studies. Biol Psychiatry 2000;48:531-538.

25. Craddock N, O'Donovan MC, Owen MJ. The genetics of schizophrenia and bipolar disorder: dissecting psychosis. J Med Genet 2005;42:193-204.

26. Fisfalen ME, Schulze TG, DePaulo JR Jr, DeGroot LJ, Badner JA, McMahon FJ. Familial variation in episode frequency in bipolar affective disorder. Am J Psychiatry 2005;162:1266-1272.

27. Schulze TG, Hedeker D, Zandi P, Rietschel M, McMahon FJ. What is familial about familial bipolar disorder? Resemblance among relatives across a broad spectrum of phenotypic characteristics. Arch Gen Psychiatry 2006;63:1368-1376.

28. O'Mahony E, Corvin A, O'Connell R, Comerford C, Larsen B, Jones R, McCandless F, Kirov G, Cardno AG, Craddock N, Gill M. Sibling pairs with affective disorders: resemblance of demographic and clinical features. Psychol Med 2002;32:55-61.

29. Okan İbiloğlu A, Çayköylü A. Clinical Features of Patients with Bipolar and Unipolar Affective Disorder whose Relatives Have Received a Mental Disorder Diagnosis. Yeni Symposium 2011;49:19-26.

30. Steinhausen HC, Foldager L, Perto G, Munk-Jørgensen P. Family aggregation of mental disorders in the nationwide Danish three generation study. Eur Arch Psychiatry Clin Neurosci 2009;259:270277.

31. Jones I, Craddock N. Do puerperal psychotic episodes identify a more familial subtype of bipolar disorder? Results of a family history study. Psychiatr Genet 2002;12:177-180.

32. Kendell RE, Chalmer JC, Platz C. Epidemiology of puerperal psychosis. Br J Psychiatry 1987;150:662-673.

33. Schopf J, Bryois C, Jonquiere M, Scharfetter C. A family hereditary study of post-partum "psychosis". Eur Arch Psychiatry Neurol Sci 1985;235:164-170.

34. Dean C, Williams RJ, brockington IF. Is puerperal psychosis the same as bipolar manic-depressive disorder? a family study. Psychol Med 1989;19:637-647.

35. Platz C, Kendell RE. A matched-control follow-up and family study of “puerperal psychosis”. Br J Psychiatr 1988;153:90-94.

36. MacKinnon DF, Zandi PP, Cooper J, Potash JB, Simpson SG, Gershon E, Nurnberger J, Reich T, DePaulo JR. Comorbid bipolar disorder and panic disorder in families with a high prevalence of bipolar disorder. Am J Psychiatry 2002:159:30-35.

37. MacKinnon DF, McMahon FJ, Simpson SG, McInnis MG, DePaulo JR. Panic disorder with familial bipolar disorder. Biol Psychatry 1997;42:90-95

38. Glick H, Endicott J, Nee J. Premenstrual changes: are they familial. Acta Psychiatr Scand 1993;88:149-155.

39. Mrad A, Mechri A, Rouissi K, Khiari G, Gaha L. Clinical characteristics of bipolar I patients according to their family history of affective disorders. Encephale 2007;33:762-767. 
40. Vanable PA, Carey MP, Carey KB, Maisto SA. Smoking among psychiatric outpatients: relationship to substance use, diagnosis, and illness severity. Psychol Addict Behav 2003;17:259-265.

41. Waxmonsky JA, Thomas MR, Miklowitz DJ, Allen MH, Wisniewski SR, Zhang H, Ostacher MJ, Fossey MD. Prevalence and correlates of tobacco use in bipolar disorder: data from the first 2000 participants in the Systematic Treatment Enhancement Program. Gen Hosp Psychiatry 2005;27:321-328.

42. Corvin A, O’Mahony E, O’Regan M, Comerford C, O’Connell R, Craddock N, Gill M. Cigarette smoking and psychotic symptoms in bipolar affective disorder. Br J Psychiatry 2001;179:35-38.
43. Ostacher MJ, Nierenberg AA, Perlis RH, Eidelman P, Borrelli DJ, Tran TB, Marzilli Ericson G, Weiss RD, Sachs GS. The relationship between smoking and suicidal behavior, comorbidity, and course of illness in bipolar disorder. J Clin Psychiatry 2006;67:1907-1911.

44. Grunebaum MF, Galfalvy HC, Nichols CM, Caldeira NA, Sher L, Dervic K, Burke AK, Mann JJ, Oquendo MA. Aggression and substance abuse in bipolar disorder. Bipolar Disord 2006;8:496502. 